\title{
DETERMINATION OF CHLORINE DIOXIDE AND CHLORITE IN WATER SUPPLY SYSTEMS BY VERIFIED METHODS
}

\author{
Jana TKÁČOVÁ ${ }^{*}$, Jarmila BOŽÍKOVÁ
}

\section{Abstract}

This work is dedicated to the development and optimization of appropriate analytical methods for the determination of chlorine dioxide and chlorite in drinking water in order to obtain accurate and correct results in the quality control of drinking water. The work deals with the development and optimization of a method for the determination of chlorine dioxide using chlorophenol red. Furthermore, a new spectrophotometric method for the determination of chlorite via bromometry using methyl orange was developed, optimized and validated. An electrochemical method for the determination of chlorite by flow coulometry was also developed, optimized and validated.

\section{INTRODUCTION}

The main task of a drinking water distribution system is to supply each consumer with a sufficient quantity as well as quality of water consistent with the regulations of the Government of the Slovak Republic No. 496/2010 Collection of Laws (including the minimal requirements of European directive 98/83/ES, annex I, parts A, B and the national requirements). The lack of suitable sources of drinking water and their unequal spatial distribution require the transport of water over long distances, whereupon physical-chemical and biological processes take place, which negatively affect its quality. To ensure the safety of drinking water and to achieve its appropriate quality during transportation to a consumer, it is necessary to assure the healthy state of the water. Disinfection is the most common way of removing the microorganisms from water. In recent years, the most common disinfectant has become chlorine dioxide. From a medical point of view it is essential to use verified methods which provide accurate and correct results for the determination of chlorine dioxide as well as its harmful by-products in drinking water systems.
Address

1 Water Research Institute, Nábr. arm. gen. L. Svobodu 5, 81249 Bratislava, Slovakia

2 Department of Sanitary and Enviromental Engineering, Faculty of Civil Engineering, Slovak University of Technology in Bratislava, Radlinskéko 11, 81368 Bratislava, Slovakia

*Corresponding author: tkacova@vuvh.sk

Key words

- Chlorine dioxide

- chlorite,

- methods of determination,

- DBPs.

\section{OVERVIEW OF METHODS FOR THE DETERMINATION OF CHLORINE DIOXIDE DISINFECTION BYPRODUCTS}

The most important disinfection by-products (DBPs) of drinking water with chlorine dioxide are chlorine, chlorite, chlorate and perchlorate. Nowadays, a number of methods have been developed for the determination of chlorine dioxide and its DBPs, especially for chlorites. In the US Environmental Protection Agency (EPA) methods (Method 327.0), a colorimetric method for the determination of chlorine dioxide and chlorites is described (DattiLIO, T. A.; 2003). This method is based on the decolorization of the Lissamine Green B (LGB) dye with chlorine dioxide. The chlorite anion is converted into chlorine dioxide with the Horseradish Peroxidase enzyme and measured via the Lissamine Green B.

During the ongoing process of the ISO and EN conversions to the Slovak technical standards (STN), there is no separate norm for the determination of chlorine dioxide in their lists. There is a special chapter focused on the determination of chlorine dioxide (4500$\mathrm{ClO}_{2}$ ) which contains publications of standard methods (STANDARD 
Methods for the Examination of Water \& Waste Water, 2005), which have been prepared and published by such American institutions as the American Public Health Association, the American Water Works Association, and the Water Environment Federation. In this publication, three methods for the determination of chlorine dioxide are described: one iodometric (B) and two amperometric methods (C and $\mathrm{E})$.

The iodometric method affords a very precise measurement of the total available strength of a solution in term of its ability to liberate iodine from iodide. However, chlorine dioxide, chlorine, chlorite and hypochlorite are not easily distinguished by this technique. It is designed primarily for standardizing $\mathrm{ClO}_{2}$ solutions needed for the preparation of temporary standards. The amperometric methods are useful when knowledge of various chlorine fractions in a water sample is desired. They distinguish various chlorine compounds of interest with a good degree of accuracy and precision, but require specialized equipment and considerable analytical skill.

Chlorine dioxide and chlorites as well as chlorine and chloramines can be determined by titration and the spectrophotometric method using DPD (N,N-diethyl-1,4-phenylendiamine) (PALIN, A.T., 1975 AND 1986). The appropriate steps of the mentioned procedure allow for the determination of different chlorine forms (native free chlorine, monochloramines, dichloroamines and chlorites). Since the method is based on a differential determination of various oxidizing agents, the presence of an interfering matrix may be a potential source of errors (GORDON G., 1998).

The determination of chlorine dioxide is closely related to the determination of several forms of free native and bound chlorine, or gross chlorine according to the Slovak technical standard STN EN ISO 7393-1 to 3. Chlorine dioxide can be determined via a modification of procedures for the determination of individual chlorine forms, but it is a very complicated and less accurate procedure for $\mathrm{ClO}_{2}$ determination.

The spectrophotometric method using an acidic chrome violet potassium salt indicator (ACKV) is based on decreasing the indicator's absorbance after its reaction with $\mathrm{ClO}_{2}$ (MASsCHELEIN, W.J. ET. AL., 1994). This method is suitable for the determination of ozone, but not for the determination of chlorites (MASscheLEIN, W. J., 1989). The disadvantage of this method lies in the complicated preparation of the reagent and problems with its stability.

The method with chlorophenol red (CPR) is based on the oxidation of the indicator at $\mathrm{pH}=5.2$ and its spectrophotometric determination at $\mathrm{pH}=10$ (HARP, D. L., 1981; Limini, B., 1984; Fletcher, I.J., 1985; SweEtin, D.L., 1996). The method is based on a decrease in CPR oxidized by chlorine dioxide. The method is specific for chlorine dioxide and does not interfere with other oxidizing agents.

The next method based on the decolorization of the indicator is the amarant method (Matisi, F., 1995; EMMERT, G. L., 2000). The decrease in absorbance is measured at $520 \mathrm{~nm}$. The method has been tested in manual as well as in automatic modes. Chlorites, chlorates, monochloramines and Fe (III) minimally interfered in this method. Also, the chlorine reacted with the amarant, but much more slowly than with the chlorine dioxide.

The spectrophotometric method with leucomethylene blue was also introduced for the determination of chlorine dioxide. Leucomethylene blue is a reduction product of methylene blue (CHEN, H., 1997). The chlorine dioxide is determined after extraction with dichloroethane. The detection limit of this method is $0.02 \mathrm{mg} \cdot \mathrm{l}^{-1}$.

Gordon et al. used flow injection analysis for the determination of chlorine dioxide and its residues (GoRDON, G., 1991). The method is based on the reactivity of the determined analytes with iodine, which exhibits different reaction velocities at different $\mathrm{pHs}$. The concentrations of the individual components are determined via the difference between the individual measurements. The method, which uses ami- noantipyrin and phenol, has also been described for chlorine dioxide determinations (WatANABE, T., 1997).

Chlorine dioxide can also be determined electrochemically. Such methods fulfill all the necessary goals expected of analytical chemistry. They are highly sensitive, selective, highly accurate and correct. Chlorine dioxide can be selectively determined from the concentration of $0.3 \mathrm{mg} . \mathrm{l}^{-1}$ using a rotary membrane electrode. Neither hypochlorite, chlorite, chlorate nor permanganate interfere (SMART, R.B., 1982). Quentel et al. described a very interesting electrochemical method for determining $\mathrm{ClO}_{2}$. They used two dyes: Alizarin RED S (Quuentel, F., 1994) and Indigo Carmin (Quuentel, F., 1996) in single experiments. The dyes reacted with $\mathrm{ClO}_{2}$, and their decrease in concentration was used to determine the $\mathrm{ClO}_{2}$. Voltammetry has been used to measure a decrease in reagent color at low-microgram per liter concentrations of $\mathrm{ClO}_{2}$. To improve the sensitivity of the method, an electrochemical preconcentration on a mercury-drop electrode was applied. Neither free and active chlorine nor chlorites interfere under the given conditions.

The in-electrode coulometric titration seems to be a promising method for determining chlorites in drinking water. Coulorimetric titrations are suitable for micro-analysis and trace analysis. Coloumetry is an "absolute" analytical method; thus, the method is independent of the direct use of the reference material. The method is suitable for determining chlorites in drinking water above a concentration of $0.01 \mathrm{mg} . \mathrm{l}^{-1}$ (Application LetTer no. 73).

The majority of common anions occurring in drinking water can be determined by ion chromatography (IC). Chlorine dioxide can be indirectly determined after its reduction to chlorite and also by the differential determination of chlorites. There are many publications about the IC method's of determination of chlorites and chlorates in drinking water adjusted with chlorine dioxide. Also, the Slovak technical standard STN EN ISO 10304-4 (2001) describes the determination of chlorites and chlorates in drinking water. The method's determination limits (LOQ) are $0.03 \mathrm{mg} .1^{-1}$ for $\mathrm{ClO}_{3}^{-}$and $0.05 \mathrm{mg} . \mathrm{l}^{-1}$ for $\mathrm{ClO}_{2}^{-}$.

Ion liquid chromatography is a useful method for determining perchlorates and was developed at the California Institute of Health (Окамото, H. ет AL 1999). In their next publication the authors investigated the stability of low perchlorate content $\left(0.5-1000 \mu \mathrm{g} . \mathrm{l}^{-1}\right)$ in underground and also in aboveground water using ion chromatography (Stetson, J., S., ET AL, 2006) because of the possibility of the long-term storage of such samples. The high stability of perchlorates in underground water (at least 300 days) and aboveground water (at least 30 days) was found. Ion chromatography with mass detection was used for determining perchlorates in drinking and waste water in concentration levels of tenths of micrograms per liter (MATHEW, J., 2005). The perchlorate content can also be determined according to the US EPA method No. 332 (2005). Ion chromatography with conductometric and MS detection was applied for the determination of chlorites by this method. The perchlorates were determined to be in the range of $0.1-10 \mu \mathrm{g} .1^{-1} \mathrm{ClO}_{4}^{-}$.

\section{OBJECTIVES OF THE STUDY}

Chlorine dioxide is commonly used for the disinfection and hygienic assurance of drinking water. The objectives of this work stem from the need to obtain more comprehensive knowledge about the behavior of chlorine dioxide and its desinfection by-products (DBPs). It was necessary to introduce appropriate methods to monitor the content of chlorine dioxide and chlorite (and possibly bromate) in drinking water, where the quality control is required by the regulations of the Government of the Slovak Republic No. 496/2010, as well as by the requirement of the European Directive 98/83/EC. The main objective was the development, optimization, verification and establishment of a 
suitable analytical method for determining chlorine dioxide and chlorites in drinking water that affords correct and reliable results.

\section{RESULTS AND DISCUSSION}

This work was focused on the processing of appropriate analytical methods for the determination of chlorine dioxide and chlorites in drinking water that afford correct and reliable results. The work was concerned with the determination of chlorine dioxide via chlorophenol red, determination of chlorites via a new spectrophotometric method using methyl orange, and an electrochemical determination of chlorites by flow-coulometry.

\subsection{Determination of chlorine dioxide using chlorophenol red}

A method for determining chlorine dioxide using chlorophenol red (CPR) has been optimized. The work follows the aforesaid publications, which conclude that the interference of chlorites, chlorates and free active chlorine (FAC) is minimal if their concentration levels are at the same or a lower level than the concentration level of the chlorine dioxide.

The first part of the work is dedicated to the verification of the concentrations and composition of the reagents. The next part of the work developed a procedure for determining chlorine dioxide at two different concentration levels $\left(0.02-0.25 \mathrm{mg} . \mathrm{l}^{-1}\right.$ and $\left.0.25-1 \mathrm{mg} . \mathrm{l}^{-1}\right)$. Special attention has been dedicated to an accurate sampling of the CPR solution since the determination of chlorine dioxide is based on a decrease in the absorbance of CPR. The sampling accuracy has been verified by weighing each CPR sampled. It was found that the main error source of the determination stems from the sampling accuracy of the CPR. The detection limit of the method has been calculated as a standard deviation of a blank value multiplied by three and is equal to $0.008 \mathrm{mg} . \mathrm{l}^{-1}$. The required detection limit (LOQ) was calculated as $30 \%$ from the $0.2 \mathrm{mg} . \mathrm{l}^{-1}$ limit, i.e., $0.06 \mathrm{mg} . \mathrm{l}^{-1}$ (according to the regulations of the Government of the Slovak Republic No. 201/2011, $\S 3$ or directive 2009/90/ES) and is higher than the first point in the calibration range of $0.02-0.25 \mathrm{mg} . \mathrm{l}^{-1}$. The CPR solution decolorized by chlorine dioxide is stable for a minimal of 24 hours. This permits the adding of reagents to the specific sample's volume directly after the collection and to finish the determination later in the laboratory. Three methods for determining chlorine dioxide were compared: the DPD titration method, the DPD spectrophotometric method, and the CPR optimized spectrophotometric method via the determination of drinking water enriched by $0.2 \mathrm{mg} . \mathrm{l}^{-1} \mathrm{ClO}_{2}$. It was found that all three methods provided the same results, although they differ in their evaluation protocols. The determination of the equivalence point of the titration method had to be quick enough prior to the vanishing of the red color and hence, was rather complicated. Thus, the method was less reproducible with its double standard deviation of $0.04 \mathrm{mg} . \mathrm{l}^{-1}$ than the other two methods with those of $0.02 \mathrm{mg} . \mathrm{l}^{-1}$. The spectrophotometric DPD calibration is much more accurate than the CPR calibration, which is a consequence of using different standards. Whereas the potassium permanganate standard is more stable than $\mathrm{ClO}_{2}$, the $\mathrm{ClO}_{2}$ standard has to be verified again prior to acquiring each point of the calibration curve, which influences the quality of the calibration curve. Despite the complicated preparation of the calibration curve, the CPR method is definitely the most suitable method for $\mathrm{ClO}_{2}$ determination at the place of collection, because the measurement itself is not difficult and because of the stability of the coloring. All the results have been summarized in the final report of the Water Research Institute (TKÁČOVÁ J., 2000). This optimized procedure for $\mathrm{ClO}_{2}$ deter- mination in water at the $0-0.25 \mathrm{mg} . \mathrm{l}^{-1}$ and $0-1 \mathrm{mg} . \mathrm{l}^{-1}$ concentration ranges has also been introduced in the Slovak technical standard STN 757151 in Appendix I (STN 75 7151, 2002):

Ranges of the concentration: $0.02-0.25 \mathrm{mg.l}^{-1}$ (or $0.25-1 \mathrm{mg.l}^{-1}$ ) chlorine dioxide

\section{Reagents:}

- citrate buffer solution: Dissolve $19.4 \mathrm{~g}$ tri-sodium citrate dehydrate $\left(\mathrm{C}_{6} \mathrm{H}_{5} \mathrm{O}_{7} \mathrm{Na}_{3} .2 \mathrm{H}_{2} \mathrm{O}\right)$ and $6.9 \mathrm{~g}$ citric acid monohydrate $\left(\mathrm{C}_{6} \mathrm{H}_{8} \mathrm{O}_{7} \cdot \mathrm{H}_{2} \mathrm{O}\right)$ in deionized water and dilute to $100 \mathrm{ml}$.

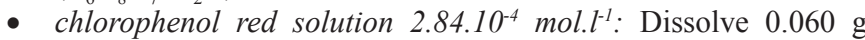
chlorophenol red in deionized water and dilute to $500 \mathrm{ml}$. The $\mathrm{pH}$ solution is adjusted to $6.5 \pm 0.2$ with $0.1 \mathrm{~mol} . \mathrm{l}^{-1} \mathrm{NaOH}$.

- 2-amino-2-methyl-1-propanol solution $\left(\mathrm{C}_{4} \mathrm{H}_{11} \mathrm{NO}\right): 17.8 \mathrm{~g}$ 2-amino-2-metyl-1-propanol is dissolved in $100 \mathrm{ml}$ deionized water.

- dechlorination reagent: $20 \mathrm{~g}$ sodium sulfite $\left(\mathrm{Na}_{2} \mathrm{~S}_{2} \mathrm{O}_{3}\right)$ is dissolved in $50 \mathrm{ml}$ deionized water.

\section{Optimized procedure}

A $1 \mathrm{ml}$ citrate buffer solution was added over the mark into two $50 \mathrm{ml}$ (or $100 \mathrm{ml}$ for the range $0.25-1 \mathrm{mg} . \mathrm{l}^{-1}$ ) volumetric flasks filled with the sample. The solutions were stirred, and $0.2 \mathrm{ml}$ of the dechlorination reagent was added to one of the flasks (blank solution). After mixing, $1 \pm 0.01 \mathrm{ml}$ (or $2 \mathrm{ml}$ for the range $0.25-1 \mathrm{mg}^{-1} \mathrm{l}^{-1}$ ) of the chlorophenol red was added to both flasks. After stirring the solutions, $1 \mathrm{ml}$ of the 2-amino-2-metyl-1-propanol solution was added, and the absorbance of the solutions was measured in a $5 \mathrm{~cm}$ cuvette (or $1 \mathrm{~cm}$ for the range $\left.0.25-1 \mathrm{mg} \cdot \mathrm{l}^{-1}\right)$ at $570 \mathrm{~nm}$.

\subsection{The photometric determination of chlorites and chlorine dioxide by bromometry - a novel solution}

Nowadays, modern separation methods such as ion liquid chromatography are widely used for the determination of chlorites and other oxo-halogenated compounds. The cost of the mentioned methods are too high for routine analysis in hydroanalytical laboratories. Hence, this work is oriented towards a determination of chlorites in drinking water at the concentration level required by the relevant legislation using commercially available equipment - a spectrophotometer.

The principle of bromometry was used to solve the submitted problem. In acidic solutions bromate behaves as a strong oxidizing agent and is reduced by many compounds to bromide, which is formed as long as an oxidized compound is present according to the following reaction:

$$
\mathrm{BrO}_{3}^{-}+6 \mathrm{H}^{+}+6 \mathrm{e}^{-} \leftrightarrow \mathrm{Br}+3 \mathrm{H}_{2} \mathrm{O}
$$

As soon as the whole oxidized reagent is fully oxidized, the excessive bromate starts to react with the created bromide to form free bromine, the presence of which even in small amounts can be indicated by the yellowing of the colorless solution or by destroying some dyes, such as methyl orange, methyl red or blue indigo disulphonic acids. The reaction is described by the reaction:

$$
\mathrm{BrO}_{3}^{-}+6 \mathrm{H}^{+}+5 \mathrm{Br} \leftrightarrow 3 \mathrm{Br}_{2}+3 \mathrm{H}_{2} \mathrm{O}
$$

The formal potential of this redox system is $1.42 \mathrm{~V}$ and indicates that bromate is a strong oxidizing agent in an acidic solution. During the titration, the first excessive drop of the bromate volumetric solution oxidizes the bromide present to bromine, which subsequently irreversibly decolorizes, e.g., methyl orange (MO), which indicates the equivalence point: 


$$
3 \mathrm{MO} \text { (red) }+3 \mathrm{Br}_{2} \leftrightarrow 3 \mathrm{MO}-\mathrm{Br}_{2} \text { (colorless) }
$$

The abovementioned reactions have been used for the photometric determination of chlorites and bromates. The decolorization sensitivity of methyl orange in the presence of bromides and the existence of possible interfering agents and their elimination have been investigated.

We also paid attention to the possible utilization of methyl orange bromation for the determination of other risky substances present in the treated drinking waters (e.g., chlorine dioxide, free active chlorine), under the application of a suitable sample pretreatment.

\section{The procedure for the determination}

Forty $\mathrm{ml}$ of the sample were added to a $50 \mathrm{ml}$ volumetric flask ( $40 \mathrm{ml}$ of distilled water in preparation of the blank solution); a fur-

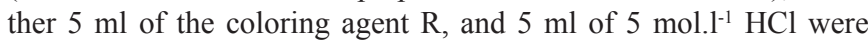
added. The whole solution was mixed and stored for 3 hours at room temperature. Subsequently, absorbance of the sample was measured in a cuvette with an optical pathway of $50 \mathrm{~mm}$ and a wavelength of $505 \mathrm{~nm}$. The value of $\Delta \mathrm{A}_{505}$ was obtained by subtraction of the measured absorbance and blank value. The weight concentration of the chlorite was calculated from the calibration curve prepared in the same way in the concentration range of $0.025-0.40 \mathrm{mg} . \mathrm{l}^{-1} \mathrm{ClO}_{2}^{-}$with a correction for the sample's dilution.

Preparation of colored agent $R: 20 \mathrm{ml}$ of $0.01 \mathrm{~mol}^{-1} \mathrm{I}^{-1}$ methyl orange was added to a $1,000 \mathrm{ml}$ volumetric flask, together with $24 \mathrm{ml}$ of 0.5 mol..$^{-1} \mathrm{NaBr}$ and a $2.7 \mathrm{ml}$ standard solution of $100 \mathrm{mg} \cdot \mathrm{l}^{-1} \mathrm{ClO}_{2}$. The coloring agent has to be prepared minimally 3 hours before usage.

The method for the determination of chlorite by methyl orange has been validated. The results of the validation are shown in Table 1 and indicate the reliability of the proposed method of determination. The detection limit (LOD) achieved was $0.006 \mathrm{mg} . \mathrm{l}^{-1}$. The working range of the method was from 0.025 to $0.4 \mathrm{mg} . \mathrm{l}^{\mathrm{l}}$. The method was linear in the whole working range. The accuracy of the method was in a range of $95.5-100.9 \%$; the trueness was in a range of $97.3-98.6$ $\%$, and both fulfilled the requirements. The recovery was $91.9 \%$. We can conclude that the validation fulfilled all the required criteria and that the method is suitable in the whole range.

All the results were processed in the final report of the Water Research Institute within the scope of the main tasks (TKÁČOVÁ J., 2002). The main objective was to determine chlorites in drinking water as well as to determine bromates according to the regulations of the Government of the Slovak Republic No. 496/2010, Collection of Laws (directive 98/83/ES).
The reliability of the new photometric method for the determination of chlorites and bromates with methyl orange in drinking water was verified by its comparison with the results obtained using the already well-established ion liquid chromatography method (Tkáčová J., 2003). The submitted method for the determination of chlorites was verified using 42 samples of drinking water obtained from two different sources, both of which used chlorine dioxide for hygienic water treatment and 68 samples collected from an end-consumer water supply network. The recoveries of the photometric method obtained as compared to the chromatographic method, was 91-122 $\%$, and both methods provided almost the same results. The verification of the reliability of the photometric determination of chlorites and bromates in drinking water using methyl orange was presented at the conference on "Drinking Water 2004" in the Czech Republic (TKÁČ́VÁ, 2004b).

The new method for determining chlorites and bromates can also be applied to the determination of chlorine dioxide and free chlorine, but due to the possible existence of several interferents, this method is mainly useful for the determination of stock solution concentrations.

\subsection{Determination of chlorites using in-electrode coulometric titration}

The photometric determination of chlorites in drinking water using $\mathrm{MO}$, in some sample cases interferes with the determination of chlorine dioxide and free chlorine. In chlorite determinations using the MO method it is necessary to analyze the interferences by other methods (i.e., free chlorine via the DPD method and chlorine dioxide via the CPR method) and to adapt the correction of the concentration of the chlorite with regard to these interferences. Although the new spectrophotometric method for the determination of chlorites and bromates represents an interesting solution of the given problem, the method still possesses some limitations. Therefore, a new suitable method for determining chlorites has been sought. Apart from ion liquid chromatography and spectrophotometry methods, chlorites in drinking water can also be determined electrochemically using the Istran instrument according to the application Note No. 73, which briefly describes the principles of the method for the determination of chlorites. It was necessary to verify the method and adapt it to our laboratory conditions. It was also necessary to introduce, optimize, validate and prepare the method for accreditation by the Slovak National Accreditation Service.

The determination uses the so-called in-electrode colorimetric titration. The chlorites in an acidic medium are electrochemically oxidized to chlorine dioxide:

Tab. 1 The final evaluation of the validation for chlorites (MO method).

\begin{tabular}{|l|c|c|c|}
\hline working characteristics & requirements & reality & conclusion \\
\hline limit of detection & $0.05{\mathrm{mg} . \mathrm{I}^{-1 *}}^{*}$ & $0,008 \mathrm{mg} . \mathrm{I}^{-1}$ & satisfy \\
\hline precision - intra-batch & $5 \%$ & $0.2-1.1 \%$ & satisfy \\
\hline precision - inter-batch & $5 \%$ & $0.2-2.0 \%$ & satisfy \\
\hline accuracy & $75-125 \%{ }^{*}$ & $95.5-100.9 \%$ & satisfy \\
\hline trueness & $75-125 \%^{*}$ & $97.3-98.6 \%$ & satisfy \\
\hline recovery & $100 \pm 25 \%^{*}$ & $91.9 \%$ & satisfy \\
\hline working range & $0.025-0.4 \mathrm{mg} . \mathrm{I}^{-1}$ & $0.025-0.4 \mathrm{mg} . \mathrm{I}^{-1}$ & satisfy \\
\hline linearity & \multicolumn{2}{|c|}{ Achieved in required range of $0.025-0.4 \mathrm{mg} . \mathrm{I}^{-1}$} \\
\hline
\end{tabular}

* Specific requirements of the relevant legislation for drinking water quality 


$$
\mathrm{ClO}_{2}^{-} \rightarrow \mathrm{ClO}_{2}+\mathrm{e}^{-}
$$

During this step the chronopotentiometric signal is recorded, and the concentration of chlorite in the sample is evaluated. The EcaFlow, model 150 GLP instrument from Istran Ltd. Bratislava with an EcaCell $104 \mathrm{C}$ measuring cell and R-101S basic electrolyte, was used. The results were evaluated using a calibration curve at a 100-200-500 $\mu \mathrm{g} . .^{-1} \mathrm{ClO}_{2}^{-}$range. It was necessary to optimize the not-normed method and prepare it for accreditation according to the Slovak technical standard STN EN ISO/IEC 17025 (2005) and to fulfill the following criteria:

- to create a standard operating procedure consistent with the manual delivered by the manufacturer,

- to perform a thorough verification of the validation parameters introduced by the manufacturer,

- to estimate the uncertainty of the measurements,

- within the scope of the verification/validation, to compare the measured results obtained by the non-standardized method with those obtained by the standardized IC method,

- to regularly verify the results obtained via the non-standardized method with proficiency testing (interlaboratory comparison).

There is no standardized method for the development of a standard operating procedure for the determination of chlorites by in-electrode coulometric titration using the EcaFlow Instrument, model 150 GLP, from Istran Ltd. Bratislava. Thus, based on the introduced application note, a standard operating procedure for determinating chlorites in drinking water was developed and optimized to fit our requirements as well as the requirements of the STN EN ISO/IEC 17025 standard.

\section{Optimization of the calibration}

The manufacturer recommends using the three point calibration curve 100-200-500 $\mu \mathrm{g} .1^{-1} \mathrm{ClO}_{2}^{-}$. Coulometry is a primary method, and the calibration is useful for verifying the accuracy of the analysis. The utilization of three calibration points was found to be unsuitable. To ensure an accurate determination due to the change in the quality of the porous carbon electrode, it was much more convenient to use a one-point calibration. The validation showed that the concentration of the calibration point of the one-point calibration curve has to be established according to the expected chlorite concentration in the sample. This value should be the same or higher than the concentration of chlorites in the sample. However, it should not exceed two times the concentration of chlorites in the sample. After the sample's measurement, it was regularly necessary to verify the validity of the one-point calibration using an accurate standard solution of chlorites.

\section{Evaluation of the validation of the chlorites}

The proposed method is fully valid. The results of the validation are summarized in Table 2. According to application note No. 73, the method range is $10-1000 \mu \mathrm{g} .1^{-1} \mathrm{ClO}_{2}^{-}$. The validation revealed the necessity to increase the lowest limit of the quantification - LOQ. Hence, the LOQ was increased from $10 \mu \mathrm{g} .1^{-1} \mathrm{ClO}_{2}^{-}$to $30 \mu \mathrm{g} \cdot 1^{-1} \mathrm{ClO}_{2}$. The upper limit of the working range is limited only by the sample's dilution.

\section{The evaluation of measuring the uncertainty}

A procedure from the literature was applied to assess the uncertainty of the measurement of the chlorites by an in-electrode coulometric titration (ISO 11352: 2012, SUCHÁNEK, M. ET AL., 2005). The uncertainty of the measurement was calculated and is equal to $\left(\mathrm{U}_{\mathrm{r}, \mathrm{tot}}\right)=14 \%$.

\section{Verification of the method}

To assess the accuracy of the results produced via in-electrode coulometric titration (ICT), the accredited ion liquid chromatography method was used according to the standard STN EN ISO 10304-4, which is commonly used for determining chlorites in drinking water treated by chlorine dioxide. Seventeen drinking water samples from one water treatment station and 3 samples from Proficiency Testing, organized by the Water Research Institute in Bratislava and CSLab Prague in 2009 - 2010, were used for the evaluation. The results of the chlorite analyses conducted by both methods, i.e., the ion chromatography method (reference method) and the in-electrode coulometry titration, were entered into a Youden graph. The slope was equal to 1.0084 (intercept $\approx 0$ ), which confirms a good agreement between the methods.

The procedure was verified by an external control - attendance at the international proficiency testing of: PT/CHA/4/2009 organized by CSLab Prague in April 2009 and PT\#V/7/2010 organized by The National Institute of Public Health (NIPH) Prague in September 2010. The analysis of the PT/CHA/4/2009 control sample by the proposed new coulometric method led to a determination of the concentration value of $135 \mu \mathrm{g} .1^{-1} \mathrm{ClO}_{2}^{-}$(the range of satisfactory results was 120 - $\left.180 \mu \mathrm{g} . \mathrm{l}^{-1}\right)$. The concentration of the PT\#V/7/2010 control sample determined by the proposed new coulometric method was $146 \mu \mathrm{g} .1^{-1}$ $\mathrm{ClO}_{2}^{-}$(the range of satisfying results was $94-196 \mu \mathrm{g} .1^{-1}$ ). This means that at both international examinations, the determination of chlorites by the optimized in-electrode coulometric titration method was successful.

Tab. 2 Results of the validation of the chlorites determined via the in-electrode coulometric titration.

\begin{tabular}{|c|c|c|c|}
\hline working characteristics & requirements & reality & conclusion \\
\hline limit of detection & $0.05 \mathrm{mg}^{\mathrm{I}^{-1 *}}$ & $0,009 \mathrm{mg} \cdot \mathrm{l}^{-1}$ & satisfy \\
\hline precision - intra-batch & $5 \%$ & $0.7-1.6 \%$ & satisfy \\
\hline precision - inter-batch & $5 \%$ & $1.6-3.8 \%$ & satisfy \\
\hline accuracy & $75-125 \% *$ & $89.0-102 \%$ & satisfy \\
\hline trueness & $75-125 \%$ * & $93.3-97.8 \%$ & satisfy \\
\hline recovery & $100 \pm 25 \% *$ & $96.7 \%$ & satisfy \\
\hline working range & $0.050-0.4 \mathrm{mg} . \mathrm{I}^{-1}$ & 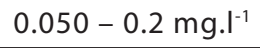 & satisfy \\
\hline linearity & \multicolumn{3}{|c|}{ Achieved in required range of $0.050-0.2{\mathrm{mg} . \mathrm{I}^{-1}}^{1}$} \\
\hline
\end{tabular}

* Specific requirements of the relevant legislation for drinking water quality 


\section{CONCLUSION}

For monitoring harmful indicators in drinking water, it is necessary to find reliable methods for their determination. The determination of chlorine dioxide and its by-products requires a high-quality instrumental technique as well as an analyst's laboratory skills. In the process of selecting a method many problems are mainly caused by non-selectivity. Many methods are non-specific at different levels of interference. It is necessary to couple the indicator determination conducted mainly at the field level (using easily accessible set-kits) with suitable laboratory methods, which are validated and the quality of whose results is regularly internally and externally controlled. Therefore, methods were developed for the determination of chlorine dioxide, the precursors from its production, and the by-products formed by chlorine dioxide water disinfection.

Many procedures for determining chlorine dioxide were tested. The spectrophotometric CPR method with minimal interferences was chosen as the most suitable one. This method was processed and optimized. The procedure for determining chlorine dioxide using chlorophenol red in ranges of the concentration $0.02-0.25 \mathrm{mg} . \mathrm{l}^{-1}$ and $0.25-1 \mathrm{mg} \cdot \mathrm{l}^{1-1}$ was developed and introduced to the Slovak technical standards and laboratory practice.

Two methods were developed for determining chlorite as precursors of chlorine dioxide production and for determining its by-products from water disinfection, which are based on various detection principles. This enables accurate determination of chlorite contents and reveals possible interferents. Initially, a new and simple photometric method was developed by the authors - a novel solution. This method is capable of determining chlorites at a concentration level required by the relevant legislation and uses an easily accessible technique - a common spectrophotometer working in a visible wavelength range. This method used the bromometry principle with methyl orange. The results obtained by this method were compared to the results obtained by the ion liquid chromatography method (standardized method), and both methods provided the same results. Further, a method for the determination of chlorites by the in-electrode coulometric titration of drinking water treated by chlorine dioxide was also optimized, developed, validated and introduced to laboratory practice by the authors. The reliability of the results was confirmed by attendance at an international proficiency testing.

The accuracy, precision, reliability and limits of the quantification of the introduced methods conformed with the relevant legislation and fulfilled the criteria of the EU directives. All the methods were verified and provided reliable results. The work results with regard to the development, optimization and introduction to practice were published.

To assess the accurate purity of chlorine dioxide, it is necessary to use suitable analytical methods which are validated and produce reliable results. Within the scope of human health protection, the legislation and all directives must regulate the presence of disinfection agents and substances introduced together into water during water treatment, as well as the by-products of disinfection. 


\section{REFERENCES}

Application Letter No. 73 Stanovenie chloritanov v dezinfikovaných vodách (The Determination of Chlorite in Disinfected Waters). Aplikácie pre EcaFlow 150 GLP, Istran s.r.o., Bratislava, Slovakia.

Dattilio, T. A. - Pepich, B. - Munch, D. J. - Fair, P. S. - Körtvélyesi, Z. - Gordon, G. (2003) Determination of Chlorine Dioxide and Chlorite Ion in Drinking Water Using Lissamine Green B and Horseradish Peroxidase with Detection by Visible Spectrophotometry. Method 327.0. US EPA, EPA-815-B-03-001 Cincinnati, $\mathrm{OH}$, p. 31

Emmert, G. L. - Coutant, D. E. - Sweetin, D. L. - Gordon, G. Bubnis, B. (2000) Studies of Selectivity in the Amaranth Method for Chlorine Dioxide. Talanta, 51, pp. 879-88.

Fletcher, I. J. - Hemmings, P. (1985) Determination of Chlorine Dioxide in Potable Waters Using Chlorophenol Red. Analyst, Vol. 110, No. 6, pp. 695-99.

Gordon, G. - Slootmaekers, B. - Tachiyashiki, S. - Wood, D.W. (1991) Minimizing Chlorite Ion and Chlorate Ion in Water Treated with Chlorine Dioxide. Journal American Water Works Association, Vol. 82, No. 4, p. 160

Gordon, G. (1998) Methods of Measuring Disinficant Residuals. Journal American Water Works Association, Vol. 80, No. 9, p. 94

Harp, D. L. - Klein, R. L., Jr. - Schoonover, D. J. (1981) Spectrophotometric Determination of Chlorine Dioxide. Journal American Water Works Association, Vol. 73, pp. 387-88.

Chen, H. - Wang, G. - Yuan, L. (1997) Extraction Spectrophotometric Determination of Trace Chlorine Dioxide with Methylene Blue. Analytical Letters Vol. 30, No. 7, pp. 1415-1421.

Limoni, B. - Choshen, E. - Rav-Acha, Ch. (1984) Determination of Oxidants Formed upon the Disinfection of Drinking Water with Chlorine Dioxide. Environmental Science and Health, Vol. 19, No. 8, pp. 943-957.

Mantisi, F. - Gautier, J.P. - Dernat, M. (1995) A Simple Robust Method for Determination of Chlorine Dioxide in Drinking Water. Proceedings of the First European Symposium on Chlorine Dioxide, 39, Rome, Italy, 7-8 Nov 1996, Collana Ambiente, Vol. 17, p. 39

Mathew, J. - Gandhi, J. - Hedrick, J. (2005) Trace Level Perchlorate Analysis by Ion Chromatography - Mass Spectrometry. Journal of Chromatography A, Vol. 1085, pp. 54-59.

Masschelein, W.J. - Fransolet, G. - Laforge, P. - Saviour, R. (1989) Determination of Residual Ozone or Chlorine Dioxide with ACVK - An Updated Version. Ozone: Sci. Eng., Vol. 11, 209-215.

Masschelein, W. J. (1994) Experience with Chlorine Dioxide in Brussels, Part 2. Journal American Water Works Association, Vol. 76, No. 3, p. 80.

Okamoto, H. - Rishl, D.K. - Steeber, W.R. - Baumann, F.J. - Pekera, S.k. (1999) Using Ion Chromatography to Detect Perchlorate. Journal American Water Works Association, Vol. 91, No. 10, p. 73.
Palin, A.T. (1975) Current DPD Methods for Residual Halogen Componnds and Ozone in Water. Journal American Water Works Association, Vol. 67, No. 1, pp. 32-33.

Palin, A.T. (1986) Current DPD Methods to Disinfectant Residual Measurement. Journal of the Institution of Water Engineers and Scientists, Vol., 40, No. 6, p. 501.

Quentel, F. - Elleouet, C. - Madec, C. (1994) Electrochemical Determination of Low Levels of Residual Chlorine Dioxide in Tap Water. Analytica Chimica Acta, Vol. 295, pp. 85-91.

Quentel, F. - Elleouet, C. - Madec, C. (1996) Determination of Trace Levels of Chlorine Dioxide in Drinking Water by Electrochemistry. Analysis, Vol. 24, pp. 199-203.

Smart, R.B. - Freese, J. W. (1982) Measuring Chlorine Dioxide with a Rotating Voltammetric Membrane Electrode. Journal American Water Works Association, Vol. 74, pp. 530-31.

Stetson, S. J. - Wanty, R. B. - Helsel, D. R. - Kalkhoff, S. J. Macalady, D. L. (2006). Stability of low levels of perchlorate in drinking water and natural water samples. Analytica chimica acta, Vol. 567, No. 1, pp. 108-113.

Suchánek, M. - Friedecký, B. - Kratochvíla, J. - Budina, M. Bartoš, V. (2006) Doporučeni pro určeni odhadu nejistot výsledku měreni/klinických testu $v$ klinických laboratořich (Recommendations for Determining the Estimate of the Uncertainties of the Measurement Result/Clinical Test in Clinical Laboratories). Klin Biochem Metab, 1, pp. 43-53.

Sweetin, D. L. - Sullivan, E. - Gordon, G. (1996) The Use of Chlorophenol Red for the Selective Determination of Chlorine Dioxide in Drinking Water. Talanta, 43, pp.103-8.

Tkáčová, J. - Marcinčin, K. - Balúchová, D. (2000) Štúdium metód stanovenia chlórdioxidu, chloritanov a bromičnanov (The Study of Methods for the Determination of Chlorine Dioxide, Chlorite and Bromate). Záverečná správa (The final report). Water Research Institute, Bratislava, Slovakia.

Tkáčová, J. - Balúchová, D. - Károlyová, D. (2002) Kontrola tvorby škodlivých vedlajšich produktov dezinfekcie pri úprave vody (Controlling the Harmful By-Products of Disinfection in Water Treatment. Záverečná správa (The final report). Water Research Institute, Bratislava, Slovakia.

Tkáčová, J. - Balúchová, D. - Károlyová, D. (2003) Overenie spol'ahlivosti fotometrického stanovenia bromičnanov a chloritanov $v$ pitných vodách pomocou metylovej oranžovej (The Verification of the Reliability of the Photometric Determination of Bromate and Chlorite in Drinking Waters and Using Methyl Orange). Záverečná správa (The final report). Water Research Institute, Bratislava, Slovakia.

Tkáčová, J. - Lenártová, D. (2004a) Stanovenie chloritanov a bromičnanov v pitných vodách - fotometria versus iónová chromatografia (The Determination of Chlorite and Bromate in Drinking Waters - Photometry versus Ion Chromatography). Hydrochémia 2004. Nové analytické metódy v chémii vody. Zborník prednášok z 36. ročníka konferencie s medzinárodnou účast’ou. Bratislava máj 2004. ZSVTS pri VÚVH. (Hydrochemistry 2004. New Ana- 
lytical Methods in the Water Chemistry. Proceedings of the 36th International Conference. Bratislava May 2004. Union of Slovak Technical Companies in the Water Research Institute), pp. 192210. ISBN 80-89062-37-7.

Tkáčová, J. - Lenártová, D. - Kútniková D. (2004b) Overenie spol'ahlivosti fotometrického stanovenia chloritanov a bromičnanov $v$ pitných vodách. (The Verification of the Reliability of the Photometric Determination of Bromate and Chlorite in Drinking Waters). Sborník konference „Pitná voda 2004“, W\&ET Team (Proceedings of the Conference on "Drinking Water 2004", W\&ET Team), České Budejovice 2004, pp. 395-400.

Tkáčová, J. - Kassai, A. - Kútniková, D. - Horváth M. D. (2010) Akreditácia metódy stanovenia chloritanov vnútroelektródovou coulometrickou titráciou (The Accreditation of the Determination of Chlorite by In-Electrode Coulometric Titration). Hydrochémia 2010. Nové analytické metódy v chémii vody. Zborník prednášok z 39. ročníka konferencie s medzinárodnou účast'ou. Slovenská vodohospodárska spoločnost' ZSVTS pri VÚVH Bratislava, máj 2010 (Hydrochemistry 2010. New Analytical Methods in Water Chemistry. Proceedings of the $39^{\text {th }}$ International Conference, Union of Slovak Technical Companies in the Water Research Institute, Bratislava, May 2010), pp. 83-92. ISBN 978-80-8906268-3

Tkáčová, J. - Horváth, M. - Kassai, A. (2011) Kontrola tvorby $D B P$ - stanovenie chloritanov (The Monitoring of the Formation of DBPs - the Determination of Chlorite). Modernizácia a optimalizácia úpravní vôd. Sborník z 2. ročníka konferencie, Stará Lesná, marec 2011 (The modernization and optimization of water treatment. Proceedings of the $2^{\text {nd }}$ Conference, Stará Lesná, March 2011), pp. 241 - 244. ISBN 978-80-969974-4-2

Watanabe, T. - Ishii, T. - Yoshimura, Y. - Nakazawa, H. (1997) Determination of Chlorine Dioxide Using 4-aminoantipyrine and Phenol by Flow Injection Analysis. Analytica chimica acta, Vol. 341, No. 2, pp. 257-262.

ISO 11352:2012 (2012) Water quality - Estimation of measurement uncertainty based on validation and quality control data.
Nariadenie vlády SR č. 496/2010, Z.z. (2010) ktorým sa meni a doplña nariadenie vlády Slovenskej republiky č. 354/2006 Z.z., ktorým sa ustanovujú požiadavky na vodu určenú na l'udskú spotrebu a kontrolu kvality vody určenej na l'udskú spotrebu (The Regulation of the Government of the Slovak Republic No. 496/2010 Coll., amending the Regulation of the Government of the Slovak Republic No. 354/2006 Coll., laying down the requirements for water intended for human consumption and control of the quality of water intended for human consumption).

Standard Methods for Examination of Water and Wastewater (2005) $A P H A, A W W A, W E F .21^{\text {st }}$ Edition, Maryland.

STN EN ISO/IEC 17025: 2001 (2001). Všeobecné požiadavky na kompetentnost' skúšobných a kalibračných laboratórii (General Requirements for Competence of Testing and Calibration Laboratories). ISO/IEC 17025: 2005.

STN EN ISO 10304-4 (75 7447): 2001 (2001) Kvalita vody - Stanovenie rozpustených aniónov iónovou kvapalinovou chromatografiou, Čast' 4: Stanovenie chlorečnanov, chloridov a chloritanov v málo znečistených vodách. (Water Quality. Determination of Dissolved Anions by Liquid Chromatography of Ions. Part 4: Determination of Chlorate, Chloride and Chlorite in Water with Low Contamination).

STN 75 7151: 2002 (2002) Kvalita vody. Požiadavky na kvalitu vody dopravovanej potrubim (Water Quality. Requirements for Water in Piping Systems).

U.S. EPA 327.0 (2005) Determination of Chlorine Dioxide and Chlorite Ion in Drinking Water Using Lissamine Green and Horseradish Peroxidase with Detection by Visible Spectrophotometry. U.S. Environmental Protection Agency, Cincinnati, Ohio 45268.

U.S. EPA 332.0 (2005) Determination of Perchlorate in Drinking Water by Ion Chromatography with Suppressed Conductivity Detector and Electrospray Ionization Mass Spectrometry. U.S. Environmental Protection Agency, Cincinnati, Ohio 45268. 